\title{
Analisis Kelayakan Butir Soal pada Media INTERMATHLY (Interesting Mathematic Monopoly)
}

\author{
Angel Ardila Suci Qurrota A'yun ${ }^{1}$, Fury Styo Siskawati², Tri Novita Irawati ${ }^{3}$ \\ 1, 2, 3 Program Studi Pendidikan Matematika, Fakultas Keguruan dan Ilmu Pendidikan, Universitas Islam Jember, \\ Jl. Kyai Mojo No. 101, Kaliwates Kidul, Kec Kaliwates, Kab Jember, Jawa Timur \\ angelardila31@gmail.com
}

\begin{abstract}
The purpose of the research is to describe the feasibility of question items on the power point-based media intermathly is applied in class VIII at SMPN 6 Jember in terms of validity, reliability, discriminating power and difficulty level. This game support device uses software Affinity Designer versi 1.8.5.703. The kind of the research is descriptive with qualitative and quantitative approaches. The sample used is 31 students with triangulation in the form source of triangulation. The data collection method uses test, and the data analysis method uses collaboration between qualitative which includes reduction, presentation and drawing conclusion, while quantitatively using SPSS. Furthermore, the research results obtained indicate that the questions used in interactive learning media in class VIII at SMPN 6 Jember are included in the good validity, very high reliability, and have good discriminating power but do not have a good difficulty level. The need for the result of this study so that interactice learning media still pay attention to the criteria for good questions and produce quality questions and will later become a reference in improving the quality of future questions. This is intended to provide the best quality for the world of education in Indonesia, especially in learning mathematics.
\end{abstract}

Keyword: question item, media intermathly

\begin{abstract}
Abstrak
Tujuan dari penelitian ini adalah untuk mendiskripsikan kelayakan butir soal pada media intermathly berbasis power point yang diterapkan di kelas VIII SMPN 6 Jember ditinjau dari validitas, reliabilitas, daya pembeda dan tingkat kesukaran. Perangkat pendukung game ini menggunakan software Affinity Designer Versi 1.8.5.703. Jenis penelitian ini yaitu deskriptif dengan pendekatan kualitatif dan kuantitatif. Sampel yang digunakan sebanyak 31 siswa dengan triangulasi yang berupa triangulasi sumber. Metode pengumpulan datanya menggunakan tes dan metode analisis datanya menggunakan kolaborasi antara kualitatif yang meliputi reduksi, penyajian dan penarikan simpulan sedangkan kuantitatifnya menggunakan SPSS. Selanjutnya hasil penelitian yang diperoleh menunjukkan bahwa soal yang digunakan pada media pembelajaran interaktif di kelas VIII SMPN 6 Jember termasuk dalam kategori validitas yang baik, reliabilitasnya sangat tinggi, dan memiliki daya pembeda yang baik namun belum memiliki tingkat kesukaran yang baik. Perlunya hasil penelitian ini agar media intermathly tetap memperhatikan kriteria soal yang baik dan menghasilkan soal yang berkualitas serta nantinya menjadi acuan dalam peningkatan kualitas soal mendatang. Hal ini dimaksudkan untuk memberikan kualitas terbaiknya bagi dunia pendidikan di Indonesia khususnya pada pembelajaran matematika.
\end{abstract}

Kata kunci: butir soal, media intermathly

Copyright (c) 2022 Angel Ardila Suci Qurrota A’yun, Fury Styo Siskawati, Tri Novita Irawati $\triangle$ Corresponding author: Fury Styo Siskawati

Email Address: furystyo@gmail.com (Jl. Kyai Mojo No. 101, Kaliwates Kidul, Kab Jember, Jawa Timur)

Received 10 December 2021, Accepted 30 January 2021, Published 06 February 2022

\section{PENDAHULUAN}

Evaluasi pendidikan merupakan proses penilaian yang tidak dapat dipisahkan dari kegiatan pembelajaran untuk mengetahui hasil dari tujuan pendidikan (Tutut kurniawan, 2015). Dalam proses penilaian guru berperan sebagai ujung tombak penyusun instrumen evaluasi pembelajaran. Evaluasi dilakukan untuk mengetahui sejauh mana tercapainya tujuan pendidikan (Ali Hamzah,2014). Dilakukannya evaluasi pendidikan juga bertujuan mengetahui sejauh mana pengetahuan siswa sehingga dapat diketahui tingkat kemampuannya. Evaluasi juga dapat membantu guru untuk mengetahui tingkat keberhasilan proses pembelajaran dan pendidikan yang ada disekolah. Seorang 
guru dituntut untuk tidak hanya memiliki kemampuan menguasai materi dan metode mengajar yang baik. Akan tetapi seorang guru juga harus dibekali dengan teknik evaluasi yang memadai. Dalam prakteknya guru harus melakukan penilaian terkait proses serta hasil belajar siswa yang nantinya akan berpengaruh dalam pengambilan keputusan mengenai tingkat kualitas capaian belajar siswa.

Ketika membahas tentang tingkat kualitas capaian belajar siswa maka salah satu instrumen pendukung yang dapat digunakan adalah soal tes. Tes merupakan alat untuk mengukur hasil belajar siswa dengan memberikan seperangkat pertanyaan atau serangkaian tugas yang wajib dikerjakan oleh siswa (Tutut kurniawan, 2015). Tes yang biasa digunakan oleh guru untuk menguji hasil belajar siswa ada 2 yaitu tes dalam bentuk soal esai dan pilihan ganda. Berkaitan dengan hal tersebut, Dalam menyampaikan materi pembelajaran dilakukan menggunakan media dan pada kegiatan evaluasi hasil belajar yang termuat pada medianya menggunakan soal-soal berbentuk pilihan ganda. Media pembelajaran yang digunakan yaitu media INTERMATHLY (Interesting Mathematic Monopoly) merupakan media pembelajaran berbasis game digital. Monopoli yang digunakan menerapkan program power point yang dikemas secara menarik guna memperkuat rasa semangat belajar yang nantinya berpengaruh pada perolehan hasil belajar siswa. Materi dan soal yang terdapat dalam media intermathly tersedia untuk tiap jenjang tingkatan kelas dan disesuaikan dengan tingkat kesukaran yang telah disusun dalam bentu level.

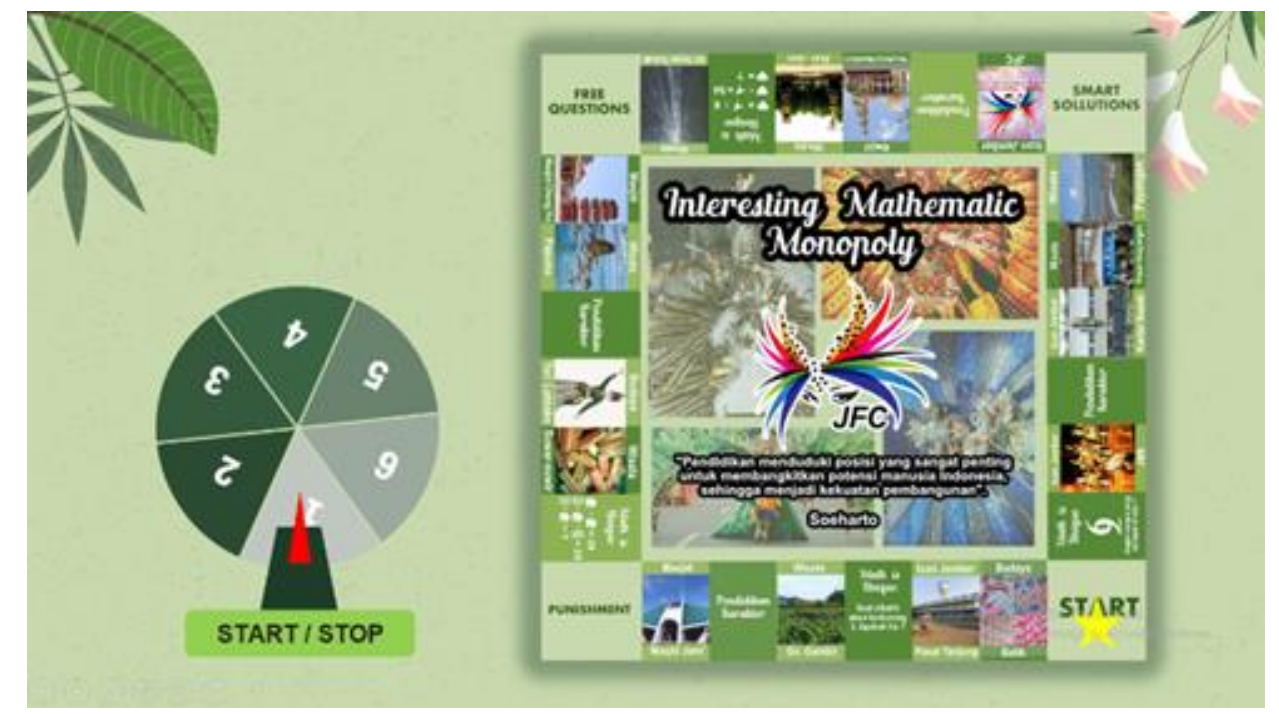

Gambar 1. Papan Permainan Intermathly

Selanjutnya informasi lain yang diperoleh, menunjukkan bahwa sejauh ini guru kurang mempunyai persiapan dalam menyusun soal yang sesuai dengan kaidah penyusunan soal yang baik. Soal yang dibuat tidak melalui tahap analisis serta hanya menggunakan soal-soal yang ada pada buku pegangan guru saja dan buku penunjang lainnya. Hal tersebut berakibat pada tidak diketahuinya kualitas butir soal pada media pembelajaran interaktif yang digunakan, tidak diketahui terkait validitas, realibilitas, daya pembeda, dan juga tingkat kesukarannya.

Ketika dianalisis lebih jauh diketahui bahwa penggunaan bentuk soal pilihan ganda dilakukan 
Analisis Kelayakan Butir Soal pada Media INTERMATHLY (Interesting Mathematic Monopoly), Angel Ardila Suci Qurrota A'yun ${ }^{1}$, Fury Styo Siskawati ${ }^{2}$, Tri Novita Irawati

untuk mengatasi kelemahan dari penggunaan soal essay. Padahal seperti yang kita ketahui penggunaan soal essay dapat meningkatkan daya analisis siswa dan kemampuan siswa untuk memberikan jawaban dengan bahasa siswa sendiri, dengan demikian keadaan ini dapat memberikan memotivasi bagi siswa untuk lebih maksimal dalam belajar. Namun demikian walaupun tes essay memiliki dampak yang bagus dalam penerapanya, tetap saja selalu ada pengiring kelemahannya. Seperti yang disampaikan (Arikunto, 2013) dikatakan bahwa tes essay dapat mempersulit guru dalam memberikan koreksi terhadap jawaban siswa karena memerlukan waktu koreksi yang lama dan sulit. Selain itu, cara mengoreksi jawaban siswa banyak dipengaruhi oleh unsur subjektif sehingga membutuhkan pertimbangan individual lebih banyak dari guru untuk menilai jawaban siswa tersebut. Kemudian untuk ketidaksiapan guru dalam menyusun soal essay yang sesuai dengan kaidah penyusunan soal yang baik melalui tahapan analisis kualitas soal terjadi karena guru memiliki berbagai macam tugas sehingga waktu yang dimiliki guru lebih banyak digunakan untuk mengerjakan tugas-tugas tersebut. Keadaan ini juga memperkuat dipilihnya soal pilihan ganda untuk digunakan dalam kegiatan evaluasi hasil belajar siswa di SMP Negeri 6 Jember.

Berdasarkan pemaparan tersebut maka dampak yang ditimbulkan berupa kurang diketahui secara pasti apakah soal yang dibuat telah menerapkan fungsinya dengan baik atau tidak. Begitu juga dengan siswa, belum dapat diketahui dengan pasti sejauh mana tingkat ketercapaian pembelajaran sesuai dengan tujuan yang telah dirancang pada materi yang dipelajari. Hal tersebut senada dengan pendapat yang menyatakan bahwa betapa penting dilakukan analisis kualitas instrumen melalui kelayakan butir soal, dengan adanya kelayakan butir soal dapat mengukur ketercapaian hasil belajar yang telah dirancang oleh guru di awal pembelajaran (Revita et al., 2018).

Selain itu pada beberapa penelitian lain dikatakan bahwa memang sangat penting dilakukan analisis terhadap kelayakan butir soal dalam upaya untuk mengukur keberhasilan proses pembelajaran yang telah dilakukan. Keberhasilan penilaian terhadap hasil belajar bergantung pada kelayakan butir soal yang digunakan. Soal tes yang baik haruslah benar-benar dapat mengukur hal-hal yang dicantumkan dalam tujuan pembelajaran yang telah dirancang. Soal tes harus benar-benar memenuhi syarat minimum sebagai soal yang baik yakni mengenai kriteria reliabilitas, validitas, daya pembeda dan tingkat kesukaran yang dipersyaratkan (Tilaar \& Hasriyanti, 2019). Pendapat lain juga menyatakan bahwa sangat penting dilakukan analisis terhadap kualitas intrumen melalui kelayakan butir soal. Hal ini dimaksudkan sebagai usaha untuk mengetahui kehandalan dan keterpercayaannya soal tes untuk mengukur ketercapaian tujuan pembelajaran yang telah dirancang. Ketika tidak dilakukan analisis terhadap kualitas intrumen melalui kelayakan butir soal sering kali berakibat pada lemahnya butir soal dalam mengukur keberhasil pembelajaran (Amalia \& Widayati, 2012).

Berdasarkan beberapa penelitian yang digunakan sebagai acuan, maka dalam pembuatan soal untuk media intermathly juga perlu memerhatikan kelayakan butir soal yang akan digunakan. Didasarkan pada hasil penelitian sebelumnya yang menggunakan media permainan monopoli contohnya penelitian Firdaus (2015) yaitu dengan adanya soal beragam yang sesuai dengan tingkatan 
taksonomi Bloom, soal yang terdapat pada media permainan milik Firdaus tersebut masih belum terlihat letak nilai kelayakannya. Untuk memperoleh soal yang memiliki nilai kelayakan dapat dilakukan melalui analisis butir soal. Berpandangan pada pemaparan tersebut maka peneliti tertarik untuk melakukan penelitian terkait analisis kelayakan butir soal pada media intermathly yang ditinjau dari validitas, reliabilitas, daya pembeda, dan tingkat kesukaran soal. Dengan demikian maka dipilihlah judul penelitian "Analisis Kelayakan Butir Soal Pada Media Intermathly".

\section{METODE}

Pendekatan yang digunakan dalam penelitian ini yaitu kuantitatif dan kualitatif dengan jenis penelitiannya yaitu deskriptif. Subjek yang digunakan dalam penelitian ini siswa kelas VIII SMPN 6 Jember. Metode pengumpulan data yang digunakan berupa tes, dengan instrumennya berupa soal tes. Kemudian juga untuk menguji kredibilitas data yang digunakan dalam penelitian dilakukan triangulasi subjek. Selanjutnya untuk analisis data yang digunakan yaitu kolaborasi antara kualitatif yang menggunakan teori Milles dan Hullberman dimana meliputi reduksi data, penyajian data dan penarikan kesimpulan dengan kuantitatifnya yang menggunakan SPSS dimana analisisnya meliputi validitas, reliabilitas, daya pembeda dan tingkat kesukaran,. Kemudian pada penyimpulan akhir nantinya terkait jawaban atas kelayakan butir soal khususnya pada kategori reliabilitas menggunakan interpretasi pada tabel 1 . Kemudian untuk validitas dan daya pembeda, karena dalam presentase maka menggunakan interpretasi pada tabel 2. Sedangkan untuk tingkat kesukaran, karena soal yang digunakan tidak memfokuskan pada jenis soal-soal HOTS hanya mengukur kemampuan standar siswa maka perbandingan yang digunakan yaitu 25\%:50\%:25\% (Alvionita, 2018), berikut disajikan tabelnya

Tabel 1. Interpretasi Validitas dan Reliabilitas

\begin{tabular}{|c|l|}
\hline \multicolumn{1}{|c|}{ Standar } & \multicolumn{1}{c|}{ Kriteria } \\
\hline $0.800<r \leq 1.000$ & Sangat tinggi \\
\hline $0.600<r \leq 0.800$ & Tinggi \\
\hline $0.400<r \leq 0.600$ & Cukup \\
\hline $0.200<r \leq 0.400$ & Rendah \\
\hline $0.000<r \leq 0.200$ & Sangat Rendah \\
\hline
\end{tabular}

Tabel 2. Interpretasi Presentase

\begin{tabular}{|c|l|}
\hline \multicolumn{1}{|c|}{ Standar } & \multicolumn{1}{c|}{ Kriteria } \\
\hline $75 \%<\mathrm{P} \leq 100 \%$ & Baik \\
\hline $50 \%<\mathrm{P} \leq 75 \%$ & Cukup Baik \\
\hline $25 \%<\mathrm{P} \leq 50 \%$ & Kurang Baik \\
\hline $0 \%<\mathrm{P} \leq 25 \%$ & Tidak Baik \\
\hline
\end{tabular}

\section{HASIL DAN DISKUSI}

Berdasarkan hasil observasi awal yang dilakukan peneliti di SMP Negeri 6 Jember, diperoleh informasi bahwa pelaksanaan pembelajaran khususnya mata pelajaran matematika dilakukan dengan memanfaatkan media interaktif. Media interaktif merupakan integrasi dari media digital termasuk 
Analisis Kelayakan Butir Soal pada Media INTERMATHLY (Interesting Mathematic Monopoly), Angel Ardila Suci Qurrota A'yun ${ }^{1}$, Fury Styo Siskawati ${ }^{2}$, Tri Novita Irawati

kombinasi dari electronic text, graphics, moving images, dan sound, ke dalam lingkungan digital yang terstruktur dan dapat dikendalikan sesuai keinginan, membuat siswa lebih senang untuk belajar sambil bermain dan lebih mudah di cerna dalam memahami materi maupun soal. Dari segi soal media intermathly ini terdapat bermacam macam variasi. Berdasarkan hasil penelitian yang telah dilakukan berikut disajikan hasil analisis datanya

Validitas

Validitas pada dasarnya merupakan suatu ukuran yang menunjukkan sejauh mana ketepatan dan kecermatan suatu instrumen yang berupa soal tes dalam melakukan fungsinya untuk mengukur (Azwar, 2010). Perhitungan validitas dilakukan menggunakan program SPSS. Selanjutnya hasil perhitungan validitas item dikorelasikan dengan $r_{\text {tabel }}$ jika $r_{\text {hitung }} \geq r_{\text {tabel }}$ maka butir soal tersebut dinyatakan valid jika sebaliknya maka tidak valid. Kriteria penerimaan dan penolaka hipotesisnya yaitu Ha diterima jika $r_{\text {hitung }} \geq r_{\text {tabel }}$, kemudian Ho ditolak jika $r_{\text {hitung }}<r_{\text {tabel. }}$

Tabel 3. Tabel Hasil Validitas

\begin{tabular}{|c|c|c|c|c|c|c|c|}
\hline No & $\mathbf{r}_{\text {hitung }}$ & $\mathbf{r}_{\text {tabel }}$ & Kriteria & No & $\mathbf{r}_{\text {hitung }}$ & $\mathbf{r}_{\text {tabel }}$ & Kriteria \\
\hline 1 & 0.678 & 0,355 & Valid & 16 & 0.830 & 0,355 & Valid \\
\hline 2 & 0.626 & 0,355 & Valid & 17 & 0.624 & 0,355 & Valid \\
\hline 3 & 0.644 & 0,355 & Valid & 18 & 0.719 & 0,355 & Valid \\
\hline 4 & 0.580 & 0,355 & Valid & 19 & 0.710 & 0,355 & Valid \\
\hline 5 & 0.317 & 0,355 & Tidak Valid & 20 & 0.515 & 0,355 & Valid \\
\hline 6 & 0.528 & 0,355 & Valid & 21 & 0.319 & 0,355 & Tidak Valid \\
\hline 7 & 0.410 & 0,355 & Valid & 22 & 0.264 & 0,355 & Tidak Valid \\
\hline 8 & 0.433 & 0,355 & Valid & 23 & 0.476 & 0,355 & Valid \\
\hline 9 & 0.616 & 0,355 & Valid & 24 & 0.438 & 0,355 & Valid \\
\hline 10 & 0.613 & 0,355 & Valid & 25 & 0.577 & 0,355 & Valid \\
\hline 11 & 0.640 & 0,355 & Valid & 26 & 0.524 & 0,355 & Valid \\
\hline 12 & 0.804 & 0,355 & Valid & 27 & 0.368 & 0,355 & Valid \\
\hline 13 & 0.583 & 0,355 & Valid & 28 & 0.467 & 0,355 & Valid \\
\hline 14 & 0.705 & 0,355 & Valid & 29 & 0.310 & 0,355 & Tidak Valid \\
\hline 15 & 0.661 & 0,355 & Valid & 30 & 0.652 & 0,355 & Valid \\
\hline
\end{tabular}

Jumlah peserta di kelas uji coba sebanyak 31 siswa. Nilai $\mathrm{r}_{\text {tabel }}$ pada taraf signifikan 5\% adalah sebesar 0,355 . Selanjutnya Dari hasil analisis validitas butir soal diperoleh 26 soal yang dinyatakan valid sedangkan 4 soal dinyatakan tidak valid. Jika dipresentasikan maka terdapat $87 \%$ soal yang valid sedangkan yang tidak valid sebesar $13 \%$.

Tabel 4. Hasil Analisis Validitas

\begin{tabular}{|c|c|c|c|c|}
\hline No & Validitas & Jumlah & No. Butir & Persentase \\
\hline 1. & $\geq 0,355$ (Valid) & 26 & $\begin{array}{c}1,2,3,4,6,7,8,9,10,11,12,13,14,15,16 \\
, 17,18,19,20,23,24,25,26,27,28,30\end{array}$ & $87 \%$ \\
\hline 2. & $<0,355$ (Tidak Valid) & 4 & $5,21,22,29$ & $13 \%$ \\
\hline
\end{tabular}

Berdasarkan hasil analisis validitas butir soal maka dapat disimpulkan bahwa butir soal yang dibuat dapat dikatakan valid dengan kriteria baik, dimana benar-benar dapat mengukur apa yang hendak diukur. Senada dengan pendapat (Sudijono, 2011) yang menyatakan bahwa validitas 
digunakan untuk mengukur ketepatan suatu instrumen tepatnya butir-butir soal yang termuat di dalamnya dalam mengukur apa yang seharusnya diukur. Walupun demikian masih dijumpai ada beberapa soal yang tidak valid, ketidak valitan ini dapat terjadi disebabkan karena adanya beberapa siswa yang menjawab salah dibagian soal yang siswa lain banyak mendapat jawaban benar, selain itu juga bisa dikarenakan bahasa yang digunakan dalam soal membingungkan untuk dipahami, serta juga dapat terjadi karena siswa hanya sekedar asal pilih tanpa membaca dan memahami soal. Pendapat lain menyatakan bahwa terdapat beberapa faktor yang bisa menyebabkan tidak validnya butir soal, adapun karena faktor instrumen evaluasi, faktor administrasi evaluasi dan penskoran, serta faktor dari jawaban siswa (Arifin, 2014). Dengan demikian makakelayakan butir soal khusunya pada kategori validitas suatu butir soal tidak hanya bergantung pada isi soal dan managemen penyususnan bahasanya saja akan tetapi juga sangat dipengaruhi oleh subjek yang mengerjakannya yaitu siswa.

\section{Reliabilitas}

Reliabilitas merupakan ukuran yang menunjukkan tingkat kekonsitenan suatu instrumen yang berupa soal digunakan sebagai alat pengumpul data dalam beberapa kali pengukuran (Arikunto, 2013). Pengujian reliabilitas dalam penelitian ini juga dilakukan dengan bantuan program SPSS. Teknik analisis reliabilitas dilakukan dengan cara mengkonversi skor tes yang diperoleh terlebih dahulu ke skor komposit. Selanjutnya dihitung reliabilitas setiap varian butir komponen serta varian skor total. Setelah semua unsur yang dibutuhkan diperoleh, selanjutnya keseluruhan unsur tersebut diaplikasikan ke rumus koefisien alpha berstrata untuk memperoleh reliabilitas komposit. Tingkat keandalan reliabilitas instrument diperoleh dengan cara menganalisis butir butir instrument yang terbukti valid. Selanjutnya untuk menyimpulkan hasil yang diperoleh berikut disajikan kategori interpretasi yang digunakan, apabila besarnya Alpha Cronbach $\geq 0,70$ maka tes yang sedang diuji dinyatakan telah memiliki reliabilitas yang tinggi. Namun apabila besarnya Alpha Cronbach < 0,70 maka tes yang sedang diuji dinyatakan belum memiliki reliabilitas yang sangat tinggi.

Adapun jumlah butir soal yang dianalisis adalah 26 dari total 30 soal hal ini dikarenakan untuk mengetahui reliabilitas cukup diambil berdasarkan soal yang valid saja. Maka selanutnya menurut hasil perhitungan diperoleh reliabilitasnya sebesar 0.877 . Dengan demikian selanjutnya ketika hasil yang diperoleh dkorelasikan denga kriteria interpretasi maka hal ini berarti tingkat reliabilitas soal berada pada kriterian Alpha Cronbach $\geq 0,70$. Oleh karena itu, dapat disimpulkan bahwa tingkat reliabilitas butir soal masuk dalam kriteria sangat tinggi.

Reliabilitas butir soal tergolong dalam kriteria tinggi dapat terjadi karena banyaknya jumlah soal, semakin banyak jumlah soal maka akan membuat soal cenderung reliable. Hal tersebut senada dengan pendapat (Sari, 2015) yang menyatakan bahwa soal dengan reliabilitas rendah dapat terjadi karena keterbatasan jumlah sehingga untuk memperbaikinya dilakukan dengan menambah jumlah butir soal khususnya butir-butir soal yang valid. Semakin banyak butir soal maka reliabilitas yang dimiliki juga semakin tinggi. Hal ini juga didukung oleh (Arikunto, 2013) yang menyatakan bahwa tes yang terdiri dari banyak butir cenderung akan lebih valid daripada yang terdiri dari sedikit butir. 
Analisis Kelayakan Butir Soal pada Media INTERMATHLY (Interesting Mathematic Monopoly), Angel Ardila Suci Qurrota A'yun ${ }^{1}$, Fury Styo Siskawati ${ }^{2}$, Tri Novita Irawati

Tinggi rendahnya validitas dapat menunjukkan tinggi rendahnya reliabilitas, semakin panjang tes maka reliabilitasnya semakin tinggi. Berdasarkan hasil penelitian yang diperoleh ketika diorelasikan dengan pendapat ahli maka memang tampak terdapat kesesuaian dimana reliabilitas tinggi pada butirbutir soal yang dibuat dapat dicapai karena jumlah soal yang banyak.

\section{Daya Pembeda}

Daya pembeda merupakan tingkat kemampuan soal untuk membedakan antarsiswa dengan kemampuan rendah (siswa yang belum menguasai kompetensi yang telah ditetapkan) dan siswa dengan kemampuan tinggi. Dalam hal ini seluruh hasil pengerjaan pada kelas uji coba diurutkan dari yang memperoleh nilai tertinggi hingga nilai yang terendah lalu dipartisi dan dikelompokkan menjadi kelompok atas dan kelompok bawah. Selanjutnya proporsi yang menjawab soal dengan benar di tiap kelompok atas dibagi dengan jumlah siswa kelompok atas, begitu juga dengan jumlah proporsi jawaban siswa kelompok bawah yang menjawab benar dibagi dengan jumlah siswa kelompok bawah. Setelah diperoleh hasil bagi dari setiap kelompok, selanjutnya dihitung selisih antara hasil bagi proporsi kelompok atas dengan kelompok bawah. Berikut kriteria daya pembeda yang digunakan

Tabel 5. Kriteria Daya Pembeda Soal

\begin{tabular}{|c|c|}
\hline Kriteria Daya Pembeda & Keterangan \\
\hline $\mathrm{DP}>0,25$ & Diterima \\
\hline $0<\mathrm{DP} \leq 0,25$ & Diperbaiki \\
\hline $\mathrm{DP} \leq 0$ & Ditolak \\
\hline
\end{tabular}

Tabel 6. Daya Pembeda Hasil

\begin{tabular}{|c|c|c|c|c|c|c|}
\hline No. & Daya Pembeda & Kriteria & & No. & Daya Pembeda & Kriteria \\
\hline 1 & 0,43 & Diterima & & 16 & 0,52 & Diterima \\
\hline 2 & 0,62 & Diterima & & 17 & 0,43 & Diterima \\
\hline 3 & 0,62 & Diterima & & 18 & 0,74 & Diterima \\
\hline 4 & 0,62 & Diterima & & 19 & 0,74 & Diterima \\
\hline 5 & 0,39 & Diterima & & 20 & 0,43 & Diterima \\
\hline 6 & 0,48 & Diterima & & 21 & $-0,03$ & Ditolak \\
\hline 7 & 0,30 & Diterima & & 22 & 0,22 & Diperbaiki \\
\hline 8 & 0,10 & Diperbaiki & & 23 & 0,27 & Diterima \\
\hline 9 & 0,48 & Diterima & & 24 & 0,24 & Diperbaiki \\
\hline 10 & 0,30 & Diterima & & 25 & 0,52 & Diterima \\
\hline 11 & 0,26 & Diterima & & 26 & 0,45 & Diterima \\
\hline 12 & 0,52 & Diterima & & 27 & 0,17 & Diperbaiki \\
\hline 13 & 0,17 & Diperbaiki & & 28 & 0,28 & Diterima \\
\hline 14 & 0,57 & Diterima & & 29 & 0,27 & Diterima \\
\hline 15 & 0,48 & Diterima & & 30 & 0,31 & Diterima \\
\hline
\end{tabular}

Setelah dilakukan analisis maka hasil yang diperoleh untuk butir soal yang ditolak sebesar $3 \%$, atau sebanyak 1 butir soal, kemudian untuk butir soal yang diperbaiki sebesar $17 \%$ atau sebanyak 3 butir soal, dan butir soal yang diterima sebesar $80 \%$ atau sebanyak 24 butir soal. Selanjutnya untuk tindak lanjut maka soal yang ditolak tidak perlu digunakan lagi, untuk soal 
diperbaiki maka masih dapat digunakan asal sudah diperbaiki, sedangkan soal yang diterima dapat langsung digunakan.

Tabel 7. Hasil Analisis Daya Pembeda

\begin{tabular}{|c|c|c|c|c|}
\hline No. & Daya Pembeda & Jumlah & Persentase & No. Butir Soal \\
\hline 1 & Ditolak & 1 & $3 \%$ & 21 \\
\hline 2 & Diperbaiki & 3 & $17 \%$ & $8,13,22,24,27$ \\
\hline 3 & Diterima & 24 & $80 \%$ & $1,2,3,4,5,6,7,9,10,11,12$, \\
& & & & $14,15,16,17,18,19,20,21,23,25,26,28,29,30$ \\
\hline
\end{tabular}

Berdasarkan hasil analisis daya pembeda butir soal maka dapat disimpulkan bahwa butir soal yang dibuat dapat dikatakan memiliki daya pembeda dengan kriteria baik. Dengan demikian maka butir soal yang dibuat sudah dapat membedakan siswa antar yang berkemampuan tiggi dengan yang berkemampua rendah. Senada dengan pendapat yang disampaikan (Fitriani, 2017) adanya analisis terhadap daya pembeda butir soal dibuat pada dasarnya untuk mengetahui perbedaan kemampuan antara siswa kelompok tinggi dan siswa kelompok rendah. Melalui daya pembeda kita dapat mengetahui bahwa butir soal jika dikerjakan oleh siswa dengan kemampuan tinggi hasilnya akan tinggi dan jika dikerjakan oleh siswa dengan kemampuan rendah hasilnya akan rendah. Jika soal tidak mamapu memebedakan kemampuan siswa siswa maka sebaiknya soal diperbaiki baik dalam segi bahasa pada soalnya ataupun pilihan jawabannya. Pendapat ahli menyatakan bahwa pada umumnya soal dapat memiliki daya pembeda yang tidak baik dapat disebabkan karena siswa yang mengerakan tidak menguasai materi sehingga berdampak pada ketidakmampuan ketika mengerjakan soal, kemudian juga bisa terjadi soal memiliki daya pembeda yang cukup baik karena siswa tidak benarbenar menguasai materi dan kebetulan ketika mengerjakan soal jawaban yang diberikan sesuai dengan kunci yang telah dibuat maka keadaan ini menyebabkan kondisi yang bias (Halik et al., 2019). Dengan demikian maka hendaknya dalam menyususn soal-soal guru harus benar-benar memahami kondisi siswa dan tingkat penguasaan siswa pada materi yang telah dipelajarai.

\section{Tingkat Kesukaran}

Tingkat kesukaran merupakan salah satu indikator yang dapat digunakan untuk menunjukkan kualitas suatu butir soal apakah termasuk dalam kategori mudah, sedang, atau sukar (Bagiyono, 2017). Selanjutnya kriteria tingkat kesurakan yang digunakan adalah sebagai berikut,

Tabel 8. Kriteria Tingkat Kesukaran Soal

\begin{tabular}{|c|c|}
\hline Kriteria Daya Pembeda & Keterangan \\
\hline $0,00-0,30$ & Sukar \\
\hline $0,31-0,70$ & Sedang \\
\hline $0,71-1,00$ & Mudah \\
\hline
\end{tabular}

Tabel 9. Tingkat Kesukaran Hasil SPSS

\begin{tabular}{|c|c|c|c|c|c|}
\hline No. & Tingkat Kesukaran & Kriteria & No. & Tingkat Kesukaran & Kriteria \\
\hline 1 & 0.680 & Sedang & 16 & 0.610 & Sedang \\
\hline 2 & 0.290 & Sukar & 17 & 0.680 & Sedang \\
\hline 3 & 0.290 & Sukar & 18 & 0.320 & Sedang \\
\hline
\end{tabular}


Analisis Kelayakan Butir Soal pada Media INTERMATHLY (Interesting Mathematic Monopoly), Angel Ardila Suci Qurrota A'yun ${ }^{1}$, Fury Styo Siskawati ${ }^{2}$, Tri Novita Irawati

\begin{tabular}{|c|c|c|c|c|c|}
\hline 4 & 0.290 & Sukar & 19 & 0.320 & Sedang \\
\hline 5 & 0.710 & Mudah & 20 & 0.680 & Sedang \\
\hline 6 & 0.650 & Sedang & 21 & 0.770 & Mudah \\
\hline 7 & 0.770 & Mudah & 22 & 0.840 & Mudah \\
\hline 8 & 0.680 & Sedang & 23 & 0.550 & Sedang \\
\hline 9 & 0.650 & Sedang & 24 & 0.320 & Sedang \\
\hline 10 & 0.770 & Mudah & 25 & 0.610 & Sedang \\
\hline 11 & 0.810 & Mudah & 26 & 0.290 & Sukar \\
\hline 12 & 0.610 & Sedang & 27 & 0.870 & Mudah \\
\hline 13 & 0.870 & Mudah & 28 & 0.290 & Sukar \\
\hline 14 & 0.580 & Sedang & 29 & 0.680 & Sedang \\
\hline 15 & 0.650 & Sedang & 30 & 0.650 & Sedang \\
\hline
\end{tabular}

Setelah dilakukan analisis maka hasil yang diperoleh untuk butir soal mudah sebesar $26.7 \%$, butir soal sedang sebesar $56.7 \%$, dan butir soal sukar sebesar $16.7 \%$. Tampak bahwa tidak terjadi keseibangan pada persentase tiap-tiap kategori soal baik mudah, sedang maupun sukar. Antara soal sukar dan mudah tampk lebih banyak soal mudah walaupun jaraknya tidak terlalu jauh.

Tabel 10. Hasil Analisis Tigkat Kesukaran

\begin{tabular}{|c|c|c|c|c|}
\hline No & Tingkat Kesukaran & Jumlah & Persentase & No. Butir Soal \\
\hline 1 & Sukar & 5 & $16,7 \%$ & $2,3,4,26,28$ \\
\hline 2 & Sedang & 17 & $56,7 \%$ & $1,6,8,9,12,14,15,16,17,18,19,20,23,24,25$ \\
& Mudah & 8 & $26,7 \%$ & $, 29,30$ \\
\hline 3 & & & $5,7,10,11,13,21,22,27$ \\
\hline
\end{tabular}

Soal dikatakan baik apabila soal yang diberikan tidak terlalu mudah dan tidak terlalu sukar, sebaliknya jika soal yang diberikan terlalu sukar akan menyebabkan siswa putus asa serta tidak bersemangat dalam mengerjakan soal begitu juga jika soal yang diberikan terlalu mudah maka akan menyebabkan siswa terlalu percaya diri dan cenderung meremehan soal (Halik et al., 2019). Kemudian untuk soal yang dikatakan berkualitas dan efektif mengukur hasil belajar jika soal memiliki keseimbangan pada tingkat kesukarannya, umumnya dipakai proporsi $1: 3: 1$, namun demikian tidak dapat juga dipatok standar pasti terkait proporsi yang dapat digunakan untuk mengukur keseimbagan tersebut, hal ini dikarenakan kualitas subjek yang mengikuti tes terkadang juga tidak berimbang. Dalam satu kelas terkadang lebih banyak siswa berkemampuan tinggi begitu juga sebaliknya. Selain itu juga dalam suatu tes terkadang tujuan yang hendak dicapai berbeda-beda jika menuntut capaian yang harus berkemampuan tinggi otomatis soal yang digunakan lebih diutamakan soal-sal sukar. Dengan demikin maka untuk patokan proporsi tingkat kesukaran dikembalikan pada subjek yang mengikuti tes dan kesepakat bersama (Bagiyono, 2017). Berpandangan pada pemaparan pendapatpendapat tersebut maka dalam penentuan tingkat kesukaran yang ada maka soal yang dibuat belum memenuhi tingkat kesukaran yang baik ditinjau dari segi proporsi begitu juga dari segi tuntutan capaiannya. Tampak bahwa soal terbanyak merupakan soal dengan kriteria mudah, jika dibiasakan mengerjakan soal-soal mudah maka nantinya siswa akan malas belajar karena cenderung menganggap bisa menyelesaikan soal-soal yang diberikan dengan mudah tanpa harus belajar dengan giat. Pada 
dasarnya keadaan tersebut dapat terjadi karena soal yang digunakan bukan soal baru dimana sudah berdasarkan hasil revisi dari tahun-tahun sebelumnya karena guru dalam memilih soal hanya mengambil dari buku pegangan dan buku penunjamh lainnya yang sudah sering dikerjakan siswa sebelumnya. Hal tersebut senada dengan yang disampaikan oleh (Mu'Arifah, 2017) penyebab ketidak seimbangan proporsi soal dapat terjadi karena soal yang dibuat guru merupakan soal-soal yang ada pada buku paket, atau juga LKS yang dibuat oleh beberapa penerbit dan juga berupa revisi soal-soal dari tahun-tahun sebelumnya sehingga soal terasa familiar bagi siswa dan merekapun mudah dalam menemukan selesaian dari soal-soal tersebut dengan demikian maka tingkat kesukaran soal menjadi rendah dan soal tergolong mudah.

Ketika membahas terkait kelayakan butir soal secara keseluruhan, beberapa pendapat menyatakan bahwa kelayakan butir soal yang kurang baik dapat terjadi karena beberapa factor diantaranya, faktor penyebab yang berasal dari dalam tes berupa tingkat kesulitan item tes tidak tepat dengan materi pembelajaran yang diterima siswa, selain itu waktu yang dialokasikan tidak tepat, hal ini termasuk kemungkinan terlalu kurang atau terlalu longgar dan jawaban masing masing item bisa diprediksi siswa. Sedangkan faktor yang berasa dari administrasi dan skor tes yaitu waktu pengerjaan tidak cukup sehingga siswa dapat memberikan jawaban dengan tergesa-gesa, adanya kecurangan dalam tes sehingga tidak membedakan antara siswa yang belajar dengan melakukan kecurangan, teknik pemberian skor yang tidak konsisten dan adanya orang lain bukan siswa yang menjawab item tes yang diberikan (Sukardi,2008). Selain itu juga dikatakan bahwa kualitas instrumen yang berupa kelayakan butir soal yang tidak baik dapat disebabkan karena kunci jawaban tidak tepat, dan butir soal memiliki jawaban ganda, kompetensi yang diukur tidak jelas, materi yang ditanyakan terlalu sulit sehingga banyak siswa yang hanya sekedar coba coba, dan sebagian besar siswa yang paham materi merasa ada yang salah dengan informasi dalam soal (Sholihah et al., 2021). Berdasarkan beberapa pendapat tersebut yang perlu untuk dipertimbagkan dalam menyusun butir soal dapat berupa pemilihan kata yang tepat, penyesuaian pertanyaan dengan tingkat pemahaman siswa, penyesuaian soal dengan SK dan KD yang telah ditetapkan, penyususnan kunci jawaban harus sesuai dengan permintaan soal, pensekoran yang realistis, penyajian soal dibuat semenarik mungkin agar siswa tidak malas memebaca soal serta penyesuaian waktu mengerjakan dengan bobot soal.

\section{KESIMPULAN}

Berdasarkan hasil penelitian yang diperoleh serta telah dipaparkan pada penyajian data hasil penelitian dan diskusi dapat disimpulkan bahwa: (1) kelayakan butir soal pada media pembelajaran interaktif yang diterapkan di SMPN 6 Jember pada masa pembelajaran daring pada kategori validitas dapat dikatakan soal memiliki validitas yang baik dimana $87 \%$ soal sudah valid. Kemudian (2) kelayakan butir soal pada media pembelajaran interaktif yang diterapkan di SMPN 6 Jember pada masa pembelajaran daring pada kategori reliabilitas dapat dikatakan soal memiliki tingkat reliabilitas yang sangat tinggi dengan Alpha Cronbach yang diperoleh sebesar 0.877. Selanjutnya untuk 
kelayakan butir soal pada media pembelajaran interaktif yang diterapkan di SMPN 6 Jember pada masa pembelajaran daring pada kategori daya pembeda dapat dikatakan soal memiliki daya pembeda yang baik dengan presentase soal yang diterimatanpa perbaikan sebanyak $80 \%$. Namun demikian untuk yang terakhir yakni kelayakan butir soal pada media pembelajaran interaktif yang diterapkan di SMPN 6 Jember pada masa pembelajaran daring pada kategori tingkat kesukaran tergolong belum memenuhi tingkat kesukaran yang baik karena ditinjau dari segi proporsi soal mudah sedang dan sukar terdapat ketidakseimbangan dimana soal mudah tampak terlalu banyak walaupun tidak terlalu jauh jarak perbandingannya dengan soal mudah. Berdasarkan hasil tersebut selanjutnya jika dilakukan sedikir perbaikan maka masalah tingkat kesukaran yang belum baik dapat berubah menjadi baik.

Dengan demikian maka berdasarkan kesimpulan yang telah dipaparkan maka saran yang dapat diajukan dalam penelitian ini yaitu, diharapkan bagi guru yang akan menggunakan media pembelajaran untuk mengupayakan adanya analisis kualitas soal baik dari aspek validitas, reliabilitas, daya pembeda, dan tingkat kesukaran. Hal ini dimaksudkan agar media pembelajaran interaktif tetap memperhatikan kriteria soal yang baik dan menghasilkan soal yang berkualitas serta nantinya menjadi acuan dalam peningkatan kualitas soal mendatang. Selain itu juga hendaknya guru selalu memberikan pelayanan maksimal khususnya pada penyusunan soal bagi siswa baik soal untuk media pembelajaran maupun soal yang lainnya hal ini dimaksudkan untuk memberikan kualitas terbaiknya bagi dunia pendidikan di Indonesia khususnya pada pembelajaran matematika. Bagi peneliti lain diharapkan penelitian ini dapat dilanjutkan pada sampel yang lebih luas sehingga guru akan lebih berkompeten di bidang evaluasi pebelajaran khususnya dalam menyusun soal untuk media pembelajaran.

\section{UCAPAN TERIMA KASIH}

Terimakasih kepada Universitas Trilogi yang telah mendanai penelitian kami hingga terselesaikannya penelitian dengan baik dan berjalan lancar. Terima kasih untuk dosen pembimbing yang telah memberi arahan selama menyelesaikan jurnal ini.

\section{REFERENSI}

Alvionita, I. L. (2018). Analisis Butir Soal Ulangan Kenaikan Kelas Di Madrasah Ibtidaiyah Kecamatan Gurah Kelas Iii Tahun Pelajaran 2017/2018. Journal of Physical Therapy Science, 9(1), 1-11. http://dx.doi.org/10.1016/j.neuropsychologia.2015.07.010\%0Ahttp://dx.doi.org/10. 1016/j.visres.2014.07.001\%0Ahttps://doi.org/10.1016/j.humov.2018.08.006\%0Ahttp://www.ncb i.nlm.nih.gov/pubmed/24582474\%0Ahttps://doi.org/10.1016/j.gaitpost.2018.12.007\%0Ahttps:// doi.org/

Amalia, A. N., \& Widayati, A. (2012). Analisis Butir Soal Tes Kendali Mutu Kelas XII Sma Mata Pelajaran Ekonomi Akuntansi Di Kota Yogyakarta. Jurnal Pendidikan Akuntansi Indonesia, $X(1), 1-26$.

Arifin, Z. (2014). Evaluasi Pembelajaran. Remaja Rosdakarya. 
Arikunto, S. (2013). Dasar dasar Evaluasi Pendidikan. Bumi Akasar.

Azwar, S. (2010). Tes Prestasi. Pustaka Pelajar.

Bagiyono. (2017). Analisis Tingkat Kesukaran dan Daya Pembeda Sial Ujian Pelatihan Radiografi

Tingkat 1. Widyanuklida, 16(No. 1), 1-12. http://repo-nkm.batan.go.id/140/1/05_ analisis_tingkat_kesukaran.pdf

England, Elaine and Finney, Andy, 2002, Interactive Media- What's that? Who's Involved?, Interactive Media UK, ATSF

Firdaus, Z. (2015). Pengembangan Media Pembelajaran Monopoli IPA Materi Sistem Pencernaan Makanan Untuk Siswa Kelas VIII Di SMP Negeri 4 Malang, Fakultas MIPA UM, 1 (1), 1-12

Fitriani. (2017). Analisis Butir Soal Ujian Akhir Sekolah (Uas) Mata Pelajaran Matematika Pada Tahun Ajaran 2015/2016 Sman 1 Pitumpanua Kecamatan Pitumpanua Kabupaten Wajo. Uin Allauddin Makassar.

Halik, A. S., Mania, S., \& Nur, F. (2019). Analisis Butir Soal Ujian Akhir Sekolah (Uas) Mata Pelajaran Matematika Pada Tahun Ajaran 2015/2016 Smp Negeri 36 Makassar. Al Asma: Journal of Islamic Education, 1(1), 11. https://doi.org/10.24252/asma.v1i1.11249

Mu’Arifah Isnani. (2017). Analisis Kualitas Butir Soal Pilihan Ganda Mata Pelajaran Biologi Kelas X Dan Xi Pada Ulangan Akhir Semester Tahun Ajaran 2016/2017 Di Man Kota Palangka Raya. IIN Palangka Raya.

Nayla Amalia, A., \& Widayati, A. (2012). Analisis Butir Soal Tes Kendali Mutu Kelas XII Sma Mata Pelajaran Ekonomi Akuntansi Di Kota Yogyakarta. Jurnal Pendidikan Akuntansi Indonesia, $X(1), 1-26$.

Revita, R., Kurniati, A., \& Andriani, L. (2018). Analisis Instrumen Tes Akhir Kemampuan Komunikasi Matematika Untuk Siswa Smp Pada Materi Fungsi Dan Relasi. Jurnal Cendekia: Jurnal Pendidikan Matematika, 2(2), 8-19. https://doi.org/10.31004/cendekia.v2i2.44

Sari, R. K. (2015). Analisis Kualitas Butir Soal Ulangan Akhir Semester Gasal Mata Pelajaran Akuntansi Keuangan Kelas Xi Akuntansi Smk Muhammadiyah Cangkringan Tahun Ajaran 2014/2015 (Vol. 3) [Universitas Negeri Yogyakarta]. http://weekly.cnbnews.com/news/article. html?no=124000

Sholihah, F., Susilaningtyas, T., \& Siskawati, F. S. (2021). The Analysis of Mathematics Question Items Quality at SMPN 01 Pakusari In the Online Learning Period. Jurnal Axioma: Jurnal Matematika Dan Pembelajaran, 6(1), 29-37.

Sudijono, A. (2011). Pengantar Evaluasi. Raja Grafindo Persada.

Tilaar, A. L. F., \& Hasriyanti. (2019). Analisis Butir Soal Semester Ganjil Mata Pelajaran Matematika pada Sekolah Menengah Pertama. Jurnal Pengukuran Psikologi Dan Pendidikan Indonesia (JP3I), 8(1), 57-68. https://doi.org/10.15408/jp3i.v8i1.13068 Education

Tutut kurniawan. (2015). Analisis Butir Soal Ulangan Akhir Semester Gasal Mata Pelajaran IPS Sekolah Dasar. Journal of Elementary Education. 